\title{
Matricaria recutita extract associated with norfloxacin or cephalexin enhances the antimicrobial activity of these drugs against Staphylococcus aureus
}

\author{
Rodrigo Rafael Maia ${ }^{1}$ \\ Andréia Vieira Pereira ${ }^{2 *}$ \\ Marcelo Biondaro Góis ${ }^{3}$ \\ Karine Delgado Souza ${ }^{3}$ \\ Vanessa de Melo Cavalcanti-Dantas ${ }^{1}$ \\ Tatiane Kelly Barbosa De Azevêdo ${ }^{4}$ \\ Cristiane Melissa Thomazini ${ }^{5}$ \\ Jozinete Vieira Pereira ${ }^{6}$ \\ Onaldo Guedes Rodrigues ${ }^{7}$ \\ Maria do Socorro Vieira Pereira ${ }^{1}$

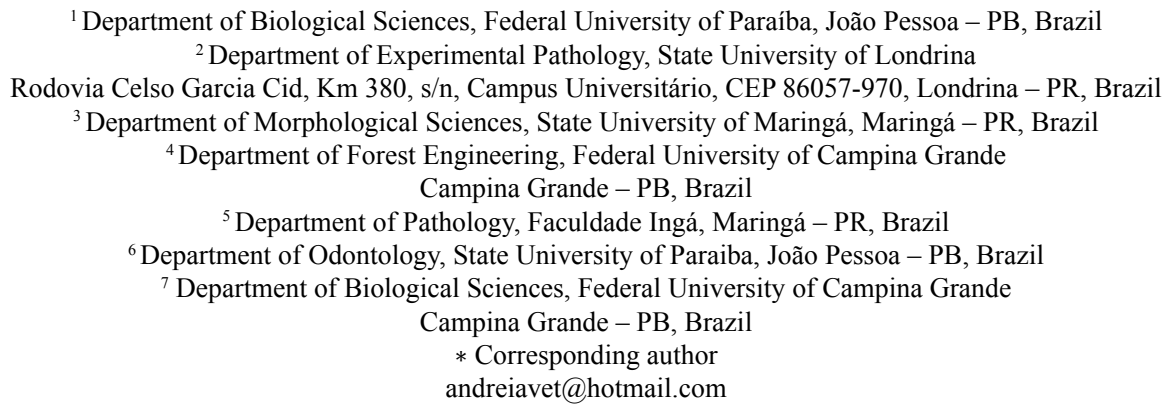

Submetido em 15/07/2016

Aceito para publicação em 17/01/2017

\section{Resumo}

Extrato de Matricaria recutita associado com norfloxacina e cefalexina aumenta a atividade antimicrobiana destes medicamentos contra Staphylococcus aureus. O surgimento de infecções bacterianas, incluindo aquelas associadas com Staphylococcus aureus, traz à tona uma necessidade de buscar novas estratégias mais eficazes para tratamento clínico. O uso de plantas medicinais associados com os antibióticos convencionais pode ser uma opção terapêutica. Atualmente, estudos evidenciam o efeito sinérgico alcançado através da combinação de extratos vegetais com antibióticos. Nosso objetivo foi avaliar a atividade antimicrobiana e cinética bacteriana in vitro do extrato de Matricaria recutita (camomila) e sua associação com cefalexina e norfloxacin sobre isolados clínicos de $S$. aureus de origem bovina, caracterizada como resistente. Os ensaios foram realizados pelo método da diluição em meio sólido para a determinação da Concentração Inibitória Mínima (CIM). Em ambas as associações do extrato de M. recutita com os antibióticos norfloxacina e cefalexina, 
foi observada CIM na diluição 1:64 o que correspondeu a $8 \mu \mathrm{g} / \mathrm{mL}$ dos antibióticos e $13.43 \mu \mathrm{g} / \mathrm{mL}$ do extrato. A associação Cefalexina com extrato de camomila produziu um efeito sinérgico em $75 \%$ das amostras na sua CIM. A combinação com produtos naturais frequentemente utilizados pela população e os antibióticos aqui ensaiados, poderiam representar uma opção terapêutica para o tratamento de infecções causadas por S. aureus, como também para prevenção do desenvolvimento crescente de resistência.

Palavras-chave: Antibióticos; Camomila; Microrganismos resistentes; Produtos naturais

\section{Abstract}

The emergence of bacterial infections, including those related to Staphylococcus aureus, has resulted in the need to search for new and more effective clinical treatment strategies. The use of medicinal plants associated with conventional antibiotics may be a therapeutic option. Currently, studies have shown the synergistic effect of combining plant extracts with antibiotics. The present study evaluated the in vitro antimicrobial activity and bactericidal kinetics of a Matricaria recutita (chamomile) extract, in association with cephalexin and norfloxacin, on clinical isolates of $S$. aureus of bovine origin, which is characterized as resistant. The tests were performed by dilution in a solid medium to determine the minimum inhibitory concentration (MIC). For both combinations of the $M$. recutita extract, with the norfloxacin and cephalexin antibiotics, we observed an MIC at a 1:64 dilution, corresponding to $8 \mu \mathrm{g} / \mathrm{mL}$ of the antibiotic and $13.43 \mu \mathrm{g} / \mathrm{mL}$ of the extract. When evaluating the MIC, cephalexin associated with the chamomile extract produced a synergistic effect in $75 \%$ of the samples. The combination of natural products frequently used by the population with the antibiotics tested in this study could be a therapeutic option for the treatment of infections caused by $S$. aureus, as well as prevent an increase in resistance.

Key words: Antibiotics; Chamomile; Natural products; Resistant microorganisms

\section{Introduction}

Staphylococcus aureus is a major nosocomial pathogen in hospital-acquired infections and is responsible for inactivating several antibiotics (CUNHA; CUNHA, 2007). Moreover, this microorganism varies widely in its sensitivity to broad-spectrum antimicrobials, making the multi-drug resistance a public health problem (STRATTON, 2000). Glycopeptides, such as vancomycin and teicoplanin, are the drugs of choice for the treatment of infections caused by methicillin-resistant $S$. aureus, which is usually resistant to $\beta$-lactam antibiotics, cephalosporins and carbapenem (OTEO; BELÉN, 2015). According to Stratton (2000), the mechanism of resistance may occur due to overproduction of $\beta$-lactamase, for strains known as BORSA (borderline oxacillin-resistant $S$. aureus), and alterations in penicillin-binding proteins (PBPs 1, 2 and 4), for strains known as MODSA (modified penicillin-binding protein $S$. aureus).

The combined use of antimicrobials, such as cephalosporins and fluoroquinolones, could possibly suppress the emergence of resistant mutant strains, and produce a synergistic in vivo effect (ZUCARELLI et al., 1988; PEREIRA et al., 2008). However, it is debatable whether conventional antimicrobials become enhanced when combined with other compounds, such as natural products.

Plants with therapeutic properties are of great importance for human and veterinary medicine worldwide (TOMAZZONI et al., 2006; SILVA et al., 2012), especially in developing countries, due to the high cost of conventional drugs (MINJA, 1994). Chamomile (Matricaria recutita Linn) belongs to the family Asteraceae (LINS et al., 2013). The pure extract of $M$. recutita is used to treat gastrointestinal disorders, oral infections, and dermatitis. In addition, it has sedative, anti-inflammatory, antifungal and antibacterial activities (ALBUQUERQUE et al., 2010a). The effects of $M$. recutita are attributed to azulene, an essential oil composed of sesquiterpene alcohol, alpha-bisabolol, and chamazulene that inhibit in vitro the chemical mediators of the inflammatory process, as well as flavonoids that inhibit the release of histamine (HILI et al., 1997; BEDI; SHENEFELT, 2002). According to Brehm-Stecher and Johnson (2003), the high concentration of alpha- 
bisabolol in the dry extract of $M$. recutita is related to antibacterial activity, and a concentration of $1 \mathrm{mg} / \mathrm{ml}$ presented bactericidal activity against $S$. aureus.

Currently, the combined use of herbal extracts or essential oils with commercial antimicrobials has become an alternative for fighting multi-resistant strains (BARRETO et al., 2014). Studies have been conducted in order to test combinations of plant extracts with conventional antibiotics, such as fluoroquinolones, against bacteria of clinical importance (MACHADO et al., 2003; MUSUMECI et al., 2003; PEREIRA et al., 2008). When associated, the effects can be enhanced, and this results in a more efficient interaction against microorganisms (ELBASHITI et al., 2011; HUSSIN; EL-SAYED, 2011; BARRETO et al., 2014). In this regard, the aim of this study was to evaluate the in vitro antimicrobial activity and bactericidal kinetics of an $M$. recutita extract, associated with cephalexin (cephalosporin) and norfloxacin (fluoroquinolone), on clinical isolates of $S$. aureus of bovine origin.

\section{Material and Methods}

\section{Plant material and extraction}

Flowers of Matricaria recutita were identified at the Laboratory of Toxicology, Department of Pharmaceutical Sciences, Universidade Federal de Pernambuco (UFPE), Recife, and archived under number 898 in the Arruda Câmara herbarium at the Universidade Estadual da Paraíba. The extraction was made at the Laboratory of Pharmaceutical Technology, Department of Pharmacy, UFPE. This procedure was conducted using the continuous-flow leaching method at room temperature, with an extraction solution of alcohol $(80 \%$ $\mathrm{v} / \mathrm{v}$ ) that was constantly restored over a $24 \mathrm{~h}$ period. We obtained $500 \mathrm{~mL}$ of extract with a final concentration of $860.00 \mu \mathrm{g} / \mathrm{mL}$ (PEREIRA et al., 2010a; 2010b).

\section{Acute toxicological assay of the Matricaria recutita extract}

Forty (40) male Swiss mice were used, which were 06-08 weeks old, had an average weight of $28 \mathrm{~g}$, and were obtained from the Sector Biotherium at the Health and
Rural Technology Center - CSTR, Universidade Federal de Campina Grande - UFCG, Campus de Patos. For the toxicological assay, the animals were allocated into 4 groups of 10 mice each, and treated with $0.25 \mathrm{~mL}$ of the plant extract, intraperitoneally (IP) in a single dose, according to the protocol established by the World Health Organization (WHO 1990-1991). Each group was treated with the extract diluted in autoclaved distilled water at concentrations of $430 \mu \mathrm{g} / \mathrm{mL}, 215 \mathrm{mg} / \mathrm{mL}, 107.5 \mathrm{mg} /$ $\mathrm{mL}$ and $53.75 \mathrm{mg} / \mathrm{mL}$, respectively. The groups were observed during a 24-hour period, maintained in an environment with a temperature of $25 \pm 3^{\circ} \mathrm{C}$, relative air humidity between 30 and $70 \%$, and $12 \mathrm{~h} / 12 \mathrm{~h}$ lightdark cycle. The animals received commercial feed and drinking water ad libitum, in order to determine the $\mathrm{LD}_{50}$.

\section{Skin irritation test}

Twenty-four hours before the test, the mid-dorsal region of the animals was shaved (area $1.5 \mathrm{~cm} \times 1.5 \mathrm{~cm}$ ) to apply the extract and observe for possible reactions. Three mice were selected for each dilution of the tested product $(430 \mu \mathrm{g} / \mathrm{mL}$ to $13.43 \mu \mathrm{g} / \mathrm{mL})$. We applied $0.5 \mathrm{~mL}$ of the dilutions on the intact skin. The application sites were covered with cotton pads attached to the skin with hypoallergenic tape. At the end of this period, the patches were removed, and excess product was removed using sterile saline. Records were obtained after observations at $3 \mathrm{~min}, 1,4,24,48$ and $72 \mathrm{~h}$ after removal, registering the skin reactions for erythema and edema, according to the calculation of the irritation index. Thus, they were classified according to the obtained index in OECD Guide no 404 (OECD, 2002) for a sensitivity and irritation test, as recommended by the Ministério da Saúde (2004).

\section{Strains of resistant Staphylococcus aureus}

Milk samples and nasal swabs were collected at the Semi-arid Research Center (NUPEÁRIDO), Patos county, PB, property of the Universidade Federal de Campina Grande (UFCG) $\left(07^{\circ} 03^{\prime} 27^{\prime}\right.$ ' to $07^{\circ} 03^{\prime} 39^{\prime \prime}$, $37^{\circ} 16^{\prime} 21^{\prime \prime}$ to $\left.37^{\circ} 16^{\prime} 38^{\prime \prime} \mathrm{W}\right)$. Samples were obtained from 30 naturally infected lactating bovines. After washing the teat with soap and water, drying it with paper towels and disinfecting the ostium with $70^{\circ} \mathrm{GL}$ ethyl alcohol, 
we aseptically collected approximately $5 \mathrm{~mL}$ of milk from each mammary quarter reactive to the "California Mastistis Test" (CMT), using a slant tube in horizontal position (CAVALCANTI-DANTAS et al., 2016).

Nasal swabs were collected and all samples were stored in sterile threaded tubes, identified and sent under refrigeration in isothermal boxes, to the Laboratory of Genetics and Microbiology at the Universidade Federal da Paraíba - CCEN, for microbiological examination and identification of $S$. aureus.

\section{Biochemical identification of Staphylococcus aureus}

Serial dilutions were made until a concentration of $10^{-5}$. An aliquot of $0.1 \mathrm{~mL}$ was distributed on petri plates containing the selective medium Baird-Parker agar, by a plating method that used a Drigalski handle. Subsequently, the plates were incubated at $37^{\circ} \mathrm{C}$ for 24-48 $\mathrm{h}$. The selected colonies were inoculated into test tubes with approximately $2 \mathrm{~mL}$ of brain heart infusion broth and incubated at $37^{\circ} \mathrm{C}$ for $24 \mathrm{~h}$. The suspected colonies were purified and confirmed by Gram stain, catalase, coagulase thermonuclease, growth in $10 \% \mathrm{NaCl}$ and anaerobic consumption of mannitol (BERGEY'S MANUAL OF DETERMINATIVE BACTERIOLOGY, 1994; SIMÕES et al., 2013). This assay was performed in triplicate.

In this study, 8 isolated strains of $S$. aureus were used: two standard samples (ATCC 29213 and ATCC 25925), one from nasal fossa (FN 121), three from lactating udders (U102, U122, U250) and two from milk (L146, L311). In order to identify the resistant strains, we previously evaluated the sensitivity to three different classes, with antibiotics, through the disk diffusion test on Petri plates containing Muller Hinton Agar (MHA) (YOUN et al., 2011). The strains were tested against $\beta$-lactam antibiotics (ampicillin and penicillin), aminoglycosides (neomycin and gentamicin) and erythromycin.

\section{Sensitivity test}

The Matricaria recutita extract was serially diluted in order to obtain concentrations ranging from 3.350 $\mu \mathrm{g} / \mathrm{mL}$ to $860.00 \mu \mathrm{g} / \mathrm{mL}$. In association, a scale of antibiotics with increasing concentrations of cephalexin and norfloxacin, ranging from 0.01565 to $512 \mu \mathrm{g} / \mathrm{mL}$, were individually added to the bacterial cultures of $S$. aureus. The bacteria were previously cultivated in BHI (Brain Heart Infusion, Sigma ${ }^{\mathrm{TM}}$ ) medium, at $37^{\circ} \mathrm{C}$ for $24 \mathrm{~h}$, and the suspensions were adjusted according to turbidity pattern corresponding to 0.5 of the McFarland nephelometric scale. This corresponds to approximately $1.5 \times 10^{8} \mathrm{CFU} / \mathrm{mL}$ (colony forming unit $/ \mathrm{mL}$ ), which was diluted in BHI broth until obtaining a concentration of $1.5 \times 10^{5} \mathrm{CFU} / \mathrm{mL}$.

Aliquots of $50 \mu \mathrm{L}$ were taken from these tubes and seeded in Petri dishes containing Muller Hinton Agar (MHA). Then, using a $6 \mathrm{~mm}$ diameter glass tube, we made wells in the culture medium, which were filled with $25 \mu \mathrm{L}$ of tannin and cephalexin diluted in distilled water. The initial concentration for the serial dilution was $500 \mathrm{mg} / \mathrm{mL}$ for the extract and $512 \mu \mathrm{g} / \mathrm{mL}$ for the antibiotics. This concentration was selected according to the results obtained by the CLSI (2010). These plates were maintained in an incubator at $37^{\circ} \mathrm{C}$ for 24 $\mathrm{h}$. The MIC was considered the lowest concentration of the drug that completely inhibited bacterial growth (PEYRET et al., 1990). The diameter of the halos of bacterial growth inhibition (CALEGARI-JACQUES, 2003; SHELBURNE et al., 2004) formed around each well was measured in millimeters. We used a qualitative method, which allowed us to classify the bacterial sample as susceptible and resistant to the association used (PEYRET et al., 1990). Based on preliminary studies (VIEIRA et al., 2009; SANTOS et al., 2011), we considered strains with halos above $10 \mathrm{~mm}$ to be sensitive.

\section{Bactericidal kinetics of the Matricaria recutita extract}

The bactericidal curve of the $M$. recutita extract was evaluated by a known method (PEYRET et al., 1990). Samples of $S$. aureus were inoculated in BHI nutrient broth, incubated at $37^{\circ} \mathrm{C}$ for 18 to $20 \mathrm{~h}$, and subcultivated in Mueller Hinton broth for $1 \mathrm{~h}$, obtaining an inoculum of $10^{5} \mathrm{CFU} / \mathrm{mL}$. A $9 \mathrm{~mL}$ aliquot of the bacterial culture was added to $1 \mathrm{~mL}$ of extract, equivalent to 10 times the 
MIC value, according to results of previous studies of our group. Another $9 \mathrm{~mL}$ aliquot of the bacterial culture was added to $1 \mathrm{~mL}$ of ethanol. The tubes were maintained in an incubator at $37^{\circ} \mathrm{C}$ for $24 \mathrm{~h}$; aliquots were taken after $2,4,6,8$ and $24 \mathrm{~h}$ of incubation and plated on blood agar. The plates were read after incubation for $48 \mathrm{~h}$ at $37^{\circ} \mathrm{C}$, using the standard plate count method. Previous studies considered the kinetics satisfactory when there was a reduction greater than or equal to $2 \log ^{10} \mathrm{CFU} / \mathrm{mL}$, for a period less than or equal to $24 \mathrm{~h}$ (SHELBURNE et al., 2004).

\section{Statistical analysis}

The sensitivity test was performed in triplicate and assessed with an analysis of variance (ANOVA), using the Kruskal-Wallis test, followed by Dunn's test, in order to compare the central tendencies of inhibiting bacterial growth (CALEGARI-JACQUES, 2003). Tests were considered significant when the $\mathrm{p}$ value was lower than $5 \%$. The data were also recorded in a database using the software SPSS (Statistical Package for Social Sciences) for Windows, version 15.0, and analyzed by descriptive and inferential statistics.

\section{Results}

The toxicity evaluation was performed with the $M$. recutita extract applied to mice. We observed that there were no manifestations of hypersensitivity reaction, itching or any other clinical signs of intoxication associated with possible hypersensitivity to the extract. The concentrations used did not kill the mice when administered intraperitoneally.

The resistance profile against $S$. aureus strains was initially checked and $12.6 \%$ were resistant to ampicillin, $11.2 \%$ to penicillin, $12.3 \%$ to neomycin, $12.6 \%$ to gentamicin and $47.5 \%$ to erythromycin.

These strains were considered resistant to the tested classes, corroborating analyses conducted in others studies (BARRETO et al., 2014). The protocol used in our study allowed us to determine the antimicrobial activity of the $M$. recutita extract associated with norfloxacin or cephalexin on samples of $S$. aureus of bovine origin, based on the minimum inhibitory concentration (MIC). The initial concentration was 512 $\mu \mathrm{g} / \mathrm{mL}$ for antibiotics and $860.00 \mu \mathrm{g} / \mathrm{mL}$ for the extract.

The inhibition halos of the $M$. recutita extract and norfloxacin had diameters ranging from 44 to 10 $\mathrm{mm}$ in all dilutions, demonstrating $100 \%$ effectiveness until a 1:512 dilution (Table 1). Growth inhibition was homogeneous, according to the concentration level of the diluted extract in association with norfloxacin. The concentration of the extract $(\mu \mathrm{g} / \mathrm{mL})$ and norfloxacin $(\mu \mathrm{g} / \mathrm{mL})$ that was $32+53.75 \mu \mathrm{g} / \mathrm{mL}$ (dilution 1:16) presented no significant difference $(\mathrm{p}=0.10)$ in the mean diameter of the inhibition halos of $S$. aureus growth. However, it was significant $(\mathrm{p}<0.05)$ when compared with the mean diameter of the halos for the concentrations (norfloxacin/extract) of (16/26.87), $(8 / 13.43) *$; the latter concentration is considered the MIC (Table 1). In the latter concentration, all strains presented sensitivity to the association, in view of their respective MICs and inhibition halos, when used alone.

Regarding the association of the $M$. recutita extract and cephalexin, the results were similar to those obtained with the combination of the extract with norfloxacin, where we obtained an MIC at a dilution of $1: 64$, corresponding to $8 \mu \mathrm{g} / \mathrm{mL}$ of the antibiotic and $13.43 \mu \mathrm{g} / \mathrm{mL}$ of the extract. For this MIC, we observed an effect for the combination in $75 \%$ of samples, i.e., only 2 samples were resistant to the association (Table 2). It is important to emphasize that the antimicrobials, when tested individually, presented halos of $28 \mathrm{~mm}$ for norfloxacin and $29 \mathrm{~mm}$ for cephalexin, for the initial concentration of $512 \mu \mathrm{g} / \mathrm{mL}$ with MICs of $64 \mu \mathrm{g} / \mathrm{mL}$ (norfloxacin) and $32 \mu \mathrm{g} / \mathrm{mL}$ (cephalexin). On the other hand, the pure extract of $M$. recutita presented halos of $22 \mathrm{~mm}$ for the concentration of $860.00 \mu \mathrm{g} / \mathrm{mL}$ with an MIC of $430 \mu \mathrm{g} / \mathrm{mL}$, but when combined, the halos ranged from $31-46 \mathrm{~mm}$, demonstrating that the in vitro antimicrobial action against these microorganisms was enhanced when using the pure extract of $M$. recutita and the evaluated antimicrobials. Thus, we observed a correlation between the decrease in tannin and cephalexin concentrations and the diameter of the inhibition halos. 
For this association, we observed that the extract has a significant pharmacological effect when associated with the antibiotics evaluated in the study, enhancing the in vitro activity of the antibiotics against these microorganisms.

The bactericidal kinetics of $M$. recutita extract were tested on a sample of $S$. aureus of bovine origin obtained from an udder (102), in which bactericidal activity was observed in the first $2 \mathrm{~h}$ of contact. In
Table 3, death kinetics for $S$. aureus were observed. In the analysis between the control and the extracts, all results were significant with decreased bacterial growth, from $5.88 \times 10^{8} \mathrm{CFU} / \mathrm{mL}$ at time zero to $6.68 \times 10^{7}$ $\mathrm{CFU} / \mathrm{mL}$ within the first hour, where partial death of bacteria occurred. In both samples there was a reduction of $2 \log 10 \mathrm{CFU} / \mathrm{mL}$ in the initial number of bacteria $(p<0.05)$ (Table 3$)$. In the analysis of the control and gentamicin, inhibition of drug was not significant.

TABLE 1: Minimum inhibitory concentration (MIC) and diameter of the inhibition halos ( $\mathrm{mm}$ ) in solid medium of the association of the Matricaria recutita (chamomile) extract (EP) with norfloxacin (Nor) against Staphylococcus aureus.

\begin{tabular}{lccccccc}
\hline & \multicolumn{7}{c}{ Concentration in $\mathbf{~ m} / \mathbf{m L}+\boldsymbol{\mu g} / \mathbf{m L}$} \\
\cline { 2 - 9 } & $\mathbf{8 6 0 + 5 1 2}$ & $\mathbf{4 3 0}+\mathbf{2 5 6}$ & $\mathbf{2 1 5}+\mathbf{1 2 8}$ & $\mathbf{1 0 7 . 5}+\mathbf{6 4}$ & $\mathbf{5 3 . 7 + 3 2}$ & $\mathbf{2 6 . 8}+\mathbf{1 6}$ & $\mathbf{1 3 . 4 + \mathbf { 8 }}$ \\
\cline { 2 - 9 } \multicolumn{1}{c}{ Microorganism } & $\mathbf{E P + N o r}$ & $\mathbf{1 : 2}$ & $\mathbf{1 : 4}$ & $\mathbf{1 : 8}$ & $\mathbf{1 : 1 6}$ & $\mathbf{1 : 3 2}$ & $\mathbf{1 : 6 4 ^ { * }}$ \\
\hline FN121 & 33 & 32 & 30 & 27 & 23 & 18 & 10 \\
U102 & 44 & 38 & 36 & 34 & 31 & 29 & 14 \\
U122 & 42 & 39 & 38 & 35 & 32 & 28 & 13 \\
U250 & 39 & 38 & 36 & 32 & 29 & 25 & 12 \\
L146 & 31 & 43 & 40 & 37 & 34 & 27 & 13 \\
L311 & 34 & 39 & 35 & 33 & 31 & 25 & 12 \\
ATCC 29213 & 40 & 39 & 37 & 31 & 28 & 24 & 12 \\
ATCC 25925 & 44 & 40 & 39 & 34 & 30 & 25 & 10 \\
\hline Mean \pm SD & $38.3 \pm 5^{\text {a }}$ & $38.5 \pm 3^{\text {a }}$ & $36.3 \pm 3^{\text {a }}$ & $32.8 \pm 2.9^{\text {a }}$ & $29.7 \pm 3.2^{\text {a }}$ & $25.1 \pm 3.3^{\text {ab }}$ & $12.0 \pm 1.4^{\text {cb }}$ \\
\hline
\end{tabular}

Means followed by the same letter were not significantly different. Kruskal-Wallis test; EP = Pure extract; FN = Nasal Fossa; U = Udder; $\mathrm{L}=$ milk; Nor= Norfloxacin;

$* \mathrm{MIC}=8 \mu \mathrm{g} / \mathrm{mL}$ (antibiotic) and $13.43 \mu \mathrm{g} / \mathrm{mL}$ (extract).

TABLE 2: Minimum inhibitory concentration (MIC) and diameter of inhibition halos ( $\mathrm{mm}$ ) in solid medium of the association of the Matricaria recutita (chamomile) extract (EP) with cephalexin (Cef) against Staphylococcus aureus.

\begin{tabular}{|c|c|c|c|c|c|c|c|}
\hline \multicolumn{8}{|c|}{ Concentration in $\mathrm{mg} / \mathrm{mL}+\mu \mathrm{g} / \mathrm{mL}$} \\
\hline \multirow[b]{3}{*}{ Microorganism } & $860+512$ & $430+256$ & $215+128$ & $107.5+64$ & $53.7+32$ & $26.8+16$ & $13.4+8$ \\
\hline & \multicolumn{7}{|c|}{ Dilutions } \\
\hline & EP + Cef & $1: 2$ & $1: 4$ & $1: 8$ & $1: 16$ & $1: 32$ & $1: 64 *$ \\
\hline FN121 & 44 & 38 & 36 & 34 & 31 & 29 & 14 \\
\hline U102 & 46 & 43 & 41 & 37 & 32 & 30 & 16 \\
\hline U122 & 40 & 39 & 36 & 34 & 29 & 26 & 00 \\
\hline U250 & 35 & 32 & 29 & 26 & 22 & 19 & 00 \\
\hline L146 & 39 & 38 & 36 & 34 & 30 & 27 & 10 \\
\hline L311 & 37 & 35 & 32 & 29 & 28 & 25 & 14 \\
\hline ATCC 29213 & 38 & 36 & 33 & 29 & 26 & 23 & 10 \\
\hline ATCC 25925 & 42 & 39 & 36 & 31 & 29 & 25 & 13 \\
\hline Mean $\pm S D$ & $40.1 \pm 3.6^{\mathrm{a}}$ & $37.5 \pm 3.2^{\mathrm{a}}$ & $34.8 \pm 5^{a}$ & $31.7 \pm 3,6^{\mathrm{a}}$ & $28.3 \pm 3^{\mathrm{a}}$ & $25.5 \pm 3,4^{\mathrm{ab}}$ & $9.6 \pm 6.2^{\mathrm{cb}}$ \\
\hline
\end{tabular}

Means followed by the same letter were not significantly different. Kruskal-Wallis test $(\mathrm{p}<0.05)$. EP = Pure extract; FN = Nasal Fossa; $\mathrm{U}=\mathrm{Udder}$; $=$ milk; Cef $=$ Cephalexin; * $\mathrm{MIC}=8 \mu \mathrm{g} / \mathrm{mL}$ (antibiotic) and $13.43 \mu \mathrm{g} / \mathrm{mL}$ (extract). 
TABLE 3: Bactericidal kinetics of the Matricaria recutita extract (chamomile) on strains of Staphylococcus aureus.

\begin{tabular}{lccccccc}
\hline \multicolumn{6}{c}{ S. aureus } & \multicolumn{6}{c}{ Time of Action of the Extract (minutes)/CFU/mL } \\
\hline & $\mathbf{0}$ & $\mathbf{3 0}$ & $\mathbf{6 0}$ & $\mathbf{2 4 0}$ & $\mathbf{3 6 0}$ & $\mathbf{8 4 0}$ & $\mathbf{1 4 4 0}$ \\
\cline { 2 - 8 } Udder T & $5.88 \times 10^{8^{*}}$ & $7.4 \times 10^{6^{*}}$ & $6.68 \times 10^{7}$ & $12.84 \times 10^{7}$ & $9.8 \times 10^{8}$ & $11.24 \times 10^{9}$ & $7.3 \times 10^{10}$ \\
Udder C & $5.88 \times 10^{8}$ & $4.7 \times 10^{7}$ & $11.26 \times 10^{7}$ & $5.72 \times 10^{8}$ & $6.56 \times 10^{9}$ & $6.92 \times 10^{10}$ & $12.33 \times 10^{11}$ \\
\hline
\end{tabular}

Udder $\mathrm{T}=$ Treated; Udder $\mathrm{C}=$ Control; Kruskal-Wallis Test $* \mathrm{p}<0.05$.

\section{Discussion}

When comparing the average of the inhibition halos produced, we found that the extract, when associated with both antibiotics tested, presented antimicrobial activity against $S$. aureus. These are relevant data, considering that the species $S$. aureus (MRSA) presents resistance to the majority of conventional antibiotics (CUNHA; CUNHA, 2007).

The anti-inflammatory, antioxidant and genotoxic activities of chamomile extracts ( $M$. recutita) have been investigated in laboratory studies and with experimental models, where concentrations that had effects ranged from $47.41 \mathrm{mg} / \mathrm{mL}$ to $40 \mathrm{~g} / \mathrm{L}$ (MORAIS et al., 2009; VIEIRA et al., 2009). Our results indicate the MICs were 1:64 dilutions, which correspond to $8 \mu \mathrm{g} / \mathrm{mL}$ of norfloxacin or cephalexin and $13.43 \mu \mathrm{g} / \mathrm{mL}$ of $M$. recutita extract, and were the optimal concentrations for the preparation of substances for clinical use. Traditionally, in vitro antimicrobial activity is assessed by measuring the MIC, which can be done by measuring halos or by determining resistance levels. However, other pharmacodynamic parameters can be used to determine antibacterial and bactericidal efficacy, such as bactericidal kinetics (SANTOS et al., 2011).

Bactericidal kinetics is an experimental method that determines the viability of the tested organisms after exposure to the extract, or antibiotic, of interest during a given period (MAY et al., 2000). Some studies considered the kinetics satisfactory when there was a reduction greater than or equal to $2 \log [10] \mathrm{CFU} / \mathrm{mL}$, for a period shorter than or equal to $24 \mathrm{~h}$ (SHELBURNE et al., 2004). Other authors have demonstrated that an $M$. recutita extract has excellent in vitro bactericidal activity against Pseudomonas aeruginosa (CARVALHO et al., 2014).
Our results demonstrate that $M$. recutita caused a decrease in the growth of $S$. aureus samples at an exposure time between 30 minutes and $4 \mathrm{~h}$. Other studies obtained similar results to ours when evaluating the synergistic activity of norfloxacin, tetracycline and erythromycin associated with an ethanol extract of Mangifera indica L. bark on S. aureus isolates (OLIVEIRA et al., 2011). These authors noted that the extract could potentially be an adjunctive source for antibiotics. According to several authors, ethanol extracts of medicinal plants can enhance the effect of commercial antimicrobials, providing, by synergism, a more efficient interaction against resistant microorganisms (ELBASHITI et al., 2011; HUSSIN; EL-SAYED, 2011). In an attempt to elucidate the mechanism of action of an $M$. recutita extract, regarding its antimicrobial activity, Brehm-Stecher and Johnson (2003) isolated active compounds and tested them alone. These authors observed, by diffusion in agar, that alpha-bisabolol, sesquiterpenes nerolidol, farnesol and apritone, in low concentrations (0.5 $\mathrm{mM}, 1 \mathrm{mM}$ and $2 \mathrm{mM}$ ), modify the permeability of membranes in microorganisms and can pass through the cell membrane of bacteria (such as $S$. aureus and E. coli). According to these authors, the alteration in membrane permeability allows the entry of exogenous substances, such as antibiotics, to the interior of bacteria, which provides a synergistic effect of the antimicrobial potential of some antibiotics, such as erythromycin, gentamicin and vancomycin, on the growth of $S$. aureus. Thus, the authors state that the increased effectiveness of sesquiterpenes in penetrating bacterial membranes may be related to the similarity of their chemical structures with the membranes, which have long carbon chains. These data corroborate Cornwell and Barry (1994), who observed that the long carbon chains in farnesol and nerolidol molecules 
play an important role in penetrating the membranes of bacterial cells, which would favor the entry of exogenous substances, such as antibiotics.

Therefore, the results obtained in this study are very significant, providing new perspectives for further research, in addition to future in vitro and in vivo clinical studies, in order to find alternative techniques for controlling bacterial infections at low concentrations with lower risk of collateral effects. Although there is a growing number of publications of in vitro models with natural products, more information and investigations are needed to elucidate the physiological processes involved in the detected antimicrobial response (ALBUQUERQUE et al., 2010b; LINS et al., 2013). New studies are also needed to better understand the possible risks and benefits of the combined use of natural products and conventional antimicrobials, because they may provide means to elucidate the mechanisms associated with bacterial resistance.

In this context, the optimization of the use of antibiotics associated with extracts or isolated phytochemicals should be based on pharmacodynamic principles, which have important implications in conducting antibiotic therapy, thus contributing to a decrease in the emergence of antibiotic resistance (PEREIRA et al., 2008).

In conclusion, the $M$. recutita extract promoted a synergistic effect of the antimicrobial potential of norfloxacin and cephalexin on the growth of $S$. aureus, enhancing antimicrobial activity and improving the in vitro effect of the drugs. This extract can be used as an important tool against antibiotic-resistant microorganisms.

\section{Acknowledgements}

The authors thank CAPES, CNPQ, and UFPB.

\section{References}

ALBUQUERQUE, A. C. L.; PEREIRA, M. S. V.; PEREIRA, J. V.; MACEDO-COSTA, M. R.; PEREIRA, L. F.; HIGINO J. S. Antimicrobial effect of Matricaria recutita Linn. (chamomile) extract against Dental Biofilm Microorganisms. Pesquisa
Brasileira em Odontopediatria e Clinica Integrada, João Pessoa, v. 10, n. 3, p. 451-455, 2010a.

ALBUQUERQUE, A. C. L.; PEREIRA, M. S. V.; PEREIRA, J. V.; MACEDO- COSTA, M. R.; PEREIRA, L. F.; HIGINO J. S. Efeito antimicrobiano do extrato da Matricaria recutita Linn. e Lippia sidoides Cham. sobre microrganismos do biofilme dental. Biofar: Revista de Biologia e Farmácia, João Pessoa, v. 4, p. 11-19, 2010 b. BARRETO, H. M.; LIMA, I. S.; COELHO, K. M. R. N.; OSÓRIO, L. R.; MOURÃO, R. A.; SANTOS, B. H. C.; COUTINHO, H. D. M.; ABREU, A. P. L.; MEDEIROS, M. G. F.; LOPES, A. M. G. Effect of Lippia origanoides H.B.K. essential oil in the resistance to aminoglycosides in methicillin resistant Staphylococcus aureus. European Journal of Integrative Medicine, London, v. 6, p. 560564, 2014.

BEDI, M. K.; SHENEFELT, P. D. Herbal theraphy in Dermatology. Archives of Dermatological Research, London, v. 138, p. 232242, 2002.

BERGEY'S MANUALOFDETERMINATIVEBACTERIOLOGY. Bacteriological analytical manual. 9. ed. Baltimore: Willians \& Wilkins, 1994. $1687 \mathrm{p}$

BREHM-STECHER, B. F.; JOHNSON, E. A. Sensitization of Staphylococcus aureus and Escherichia coli to antibiotics by the sesquiterpenoids nerolidol, farnesol, bisabolol, and apritone. Antimicrobial Agents of Chemotherapy, Washington, v. 47, p. 3357-3360, 2003.

CALEGARI-JACQUES, S. M. Bioestatística: princípios e aplicações. Porto Alegre: Artmed, 2003. 264 p.

CARVALHO, A. F.; SILVA, D. M.; SILVA, T. R. C.; SCARCELLI, E.; MANHANI, M. R. Avaliação da atividade antibacteriana de extratos etanólico e de ciclohexano a partir das flores de camomila (Matricaria chamomilla L.). Revista Brasileira de Plantas Medicinais, Paulínia, v. 16, p. 521-526, 2014.

CAVALCANTI-DANTAS, V. M. C.; MEDEIROS, K. L.; AZEVÊDO, T. K. B.; SANTANA, G. M.; PEREIRA, A. V.; GOÍS, M. B.; PEREIRA, M. S. V.; PEREIRA, J. V. Taninos: principal componente do extrato Piptadenia stipulacea (Benth) Ducke inibe o crescimento de cepas clínicas de Staphylococcus aureus de origem bovina. Biotemas, Florianópolis, v. 29, n. 1, p. 109-114, 2016.

CLSI - CLINICAL AND LABORATORY STANDARDS INSTITUTE. Performance standards for antimicrobial susceptibility testing, twentieth information supplement. Vol. 32, n. 3. Wayne: CLSI, 2010. 264 p.

CORNWELL, P. A.; BARRY, B. W. Determination of the mode of action of sesquiterpene skin penetration enhancers. Journal Pharmacy and Pharmacology, London, v. 43, p. 56, 1994.

CUNHA, A. S.; CUNHA M. R. Toxinfecção alimentar por Staphylococcus aureus através do leite e seus derivados, bem como o elevado potencial patogênico de resistência às drogas. Revista Saúde e Meio Ambiente, Três Lagoas, v. 2, p. 105-114, 2007.

ELBASHITI, T. A.; ELMANAMA, A. A.; MASAD, A. A. Antibacterial and synergistic effects of some Palestinian plant extract on Escherichia coli and Staphylococcus aureus. Funcional Plant Science \& Biotechnology, Stockholm , v. 5, p. 57-62, 2011.

HILI, P.; EVANS, C. S.; VENESS, R. G. Anti microbial action of essencial oils: the effect of dimethylsulphoxide on the activity of cinnamon oil. Letters in Applied Microbiology, Malden, v. 24, p. 269-275, 1997. 
HUSSIN, W. W.; EL-SAYED, W. M. Sybergic interactions between selecyed botanical extracts and tetracycline against Gram positive and Gram positive bacteria. Journal of Biological Sciences, Faisalabad, v. 11, p. 433-441, 2011.

LINS, R.; VASCONCELOS, F. H. P.; LEITE, R. B.; COELHOSOARES, R. S.; BARBOSA, D. N. Avaliação clínica de bochechos com extratos de aroeira (Schinus terebinthifolius) e camomila (Matricaria recutita L.) sobre a placa bacteriana e a gengivite. Revista Brasileira de Plantas Medicinais, Paulínia, v. 15, p. 112120, 2013.

MACHADO, T. B.; LEAL, I. C. R.; AMARAL, F. A. C.; SANTOS, K. R. N.; SILVA, M. G.; KUSTER, R. M. Antimicrobial ellagitannin of Punica granatum fruits. Journal Brazilian Chemical Society, São Paulo, v. 13, p. 606-610, 2003.

MAY, J.; CHAN, C. H.; FRENCH, G. C. Time-kill studies of tea tree oils on clinical isolates. Journal of Antimicrobial Chemotherapy, Oxford, v. 45, p. 639-643, 2000.

MINISTÉRIO DA SAÚDE. Guia para a realização de estudos de toxicidade pré-clínica de fitoterápicos. Resolução RE no 90, de 18 de março de 2004. Diário Oficial da República Federativa do Brasil, Brasília: Imprensa Oficial; março 2004. Seção 1.

MINJA, M. M. Medicinal plants used in promotion of animal health in Tanzania. Revue Scientifique et Technique Office International des Épizooties, Paris, v. 13, p. 905-925, 1994.

MORAIS, S. M.; CAVALCANTI, E. S. B.; COSTA, S. M. O.; AGUIAR, L. A. Ação antioxidante de chás e condimentos de grande consumo no Brasil. Revista Brasileira de Farmacognosia, Curitiba, v. 19, p. 315-320, 2009.

MUSUMECI, R.; SPECIALE, A.; COSTANZO, R.; ANNINO, A.; RAGUSA, S.; RAPISARDA, A.; PAPPALARDO, M. S.; IAUK, L. Berberis aetnensis C. Presl. extracts: antimicrobial propertie sand interaction with ciprofloxacin. Journal Antimicrobial Agents, Henderson, v. 22, p. 48-53, 2003.

OLIVEIRA, S. M. S.; FALCÃO-SILVA, V. S.; SIQUEIRAJÚNIOR, J. P.; COSTA, M. J. C.; DINIZ, M. F. F. M. D. Modulation of drug resistance in Staphylococcus aureus by extract of mango (Mangifera indica) peel. Brazilian Journal of Pharmacognosy, João Pessoa, v. 21, p. 190-193, 2011.

OECD. Guideline for testing chemical. $N^{o}$ 404. 2002. Acute dermal Irritation/corrosion. Disponível em: <http://www.oecdilibrary.org/environment/test-no-404-acute-dermal-irritationcorrosion_9789264070622-en>.

OTEO, J.; BELÉN, A. M. Molecular characterization of resistance mechanisms: methicillin resistance Staphylococcus aureus, extended spectrum $\beta$-lactamases and carbapenemases. Enfermedades Infecciosas y Microbiología Clínica, Madrid, v. 2, p. 27-33, 2015.

PEREIRA, A. V.; TREVISAN, L. F. A.; AZEVÊDO, T. K. B.; OLIVEIRA, K. A.; HIGINO, S. S. S.; COSTA, M. R. M.; PEREIRA, M. S. V.; RODRIGUES, O. G.; LIMA, E. Q. Atividade antimicrobiana in vitro do extrato da romã (Punica granatum Linn.) e alecrim-pimenta (Lippia sidoides Cham.) sobre plasmídios de Staphylococcus aureus de origem animal. Biofar: Revista de Biologia e Farmácia, João Pessoa, v. 4, p. 4-10, 2010a.

PEREIRA, A. V.; TREVISAN, L. F. A.; AZEVÊDO, T. K. B.; OLIVEIRA, K. A.; HIGINO, S. S. S.; COSTA, M. R. M.; PEREIRA, M. S. V.; RODRIGUES, O. G.; LIMA, E. Q. Avaliação comparativa: extratos vegetais de Solanum paniculatum Linnaeus e Piptadenia stipulacea (Benth) Ducke sobre Staphylococcus aureus bovinos. Agropecuária Técnica, Areia, v. 31, p. 180-184, 2010b.

PEREIRA, M. S. V.; MACEDO-COSTA, M. G.; TARGINO, M. V. P.; PEREIRA, M. V.; SIQUEIRA-FILHO, J. P.; TAKAKI, G. M. C.; BEZERRA, D. A. C.; LÔBO, K. M. S. Efeito pós-antibiótico de fluorquinolonas isoladas e em associação com cefalosporina sobre amostras de Staphylococcus aureus de origem humana e bovina. Agropecuária Científica no Semi-Árido, Campina Grande, v. 4, p. 18-26, 2008.

PEYRET, M.; CARRET, G.; CARRE, C.; FARDEL, G.; FLANDROIS, J. P. Etude mathematique de la curve de mortalite d' Echerichia coli exposes aux polymixines. Pathologie et Biologie, Paris, v. 38, p. 441-445, 1990.

SANTOS, V. L.; SOUZA, M. F. V.; BATISTA, L. M.; SILVA, B. A.; LIMA, M. S.; SOUZA, A. M. F.; BARBOSA, F. C.; CATÃO, R. M. R. Evaluation of the antimicrobial activity of Maytenus rigida Mart. (Celastraceae). Revista Brasileira de Plantas Medicinais, Paulínia, v. 13, p. 68-72, 2011.

SHELBURNE, S. A.; MUSHER, D. M.; HULTEN, K.; CEASAR, H.; LU, M. Y.; BHALIA, I.; HAMIL, R. J. In vitro killing of community-associated methicillin-resistant Staphylococcus aureus with drug combinations. Antimicrobial Agents and Chemotherapy, Washington, v. 48, p. 4016-4019, 2004.

SILVA, S. M. F. Q.; PINHEIRO, S. M. B.; QUEIROZ, M. V. F.; PRANCHEVICIUS, M. C.; CASTRO, J. G. D.; PERIM, M. C.; CARREIRO, S. C. Atividade in vitro de extratos brutos de duas espécies vegetais do cerrado sobre leveduras do gênero Candida. Ciência e Saúde Coletiva, Rio de Janeiro, v. 17, p. 1649-1656, 2012.

SIMÕES, T. V. M. D.; OLIVEIRA, A. A.; TEIXEIRA, K. M.; RODRIGUES JÚNIOR, A. S.; FREITAS, I. M. Identificação laboratorial de Staphylococcus aureus em leite bovino. Documento 180. Aracaju: Embrapa Tabuleiros Costeiros, 2013. $15 \mathrm{p}$.

STRATTON, C. W. Nuances in antimicrobial susceptibility testing for resistant Gram-positive organisms. Antimicrobics and Infectious Diseases Newsletter, New York, v. 18, p. 57-64, 2000.

TOMAZZONI, M. I.; NEGRELLE, R. R. B.; CENTA, M. L. Fitoterapia popular: a busca instrumental enquanto prática terapêutica. Texto \& Contexto Enfermagem, Florianópolis, v. 15, p. $115-121,2006$.

VIEIRA, A.; GUIMARÃES, M. A.; DAVID, G. Q.; KARSBURG, I. V.; CAMPOS, A. N. R. Efeito genotóxico da infusão de capítulos florais de camomila. Revista Trópica: Ciências Agrária e Biológicas, Chapadinha, v. 3, n. 1, p. 8-13, 2009.

YOUN, J. H.; YOON, J. W.; KOO, H. C.; LIM, S. K.; PARK, Y. H. Prevalence and antimicrogram of Staphylococcus intermedius group isolates from veterinary staff, companion animals, and the environment in veterinary hospitals in Korea. Journal of Veterinary Diagnostic Investigation, Thousand Oaks, v. 23, n. 2, p. 268-274, 2011.

ZUCCARELLI, M.; SIMEON, B. M.; MAILlOLS, H. Effet post-antibiotique de la ciprofloxaxine seule et en association sur Streptococcus faecalis. Pathologie et Biologie, Paris, v. 36, p. 410 $413,1988$. 